\title{
Case Report \\ The Role of a Rapid Prevention of Ralstonia pickettii Growth during Dialysis in a Frail Patient
}

\author{
Manuela Colosimo ${ }^{1}$, Maria Lucia Citraro ${ }^{2}$, Cinzia Donato ${ }^{2}$, Filippo Luciani ${ }^{3}$, Luca Gallelli ${ }^{4, *(D)}$ \\ and Pasquale Minchella ${ }^{1}$ \\ 1 Operative Unit of Microbiology and Virology, "Pugliese Ciaccio" Hospital, 88100 Catanzaro, Italy; \\ manuelacolosimo@hotmail.it (M.C.); minchellap@libero.it (P.M.) \\ 2 Operative Unit of Kidney Disease "Pugliese Ciaccio" Hospital, 88100 Catanzaro, Italy; \\ marialucia.citraro@gmail.com (M.L.C.); cinzia.donato@libero.it (C.D.) \\ 3 Department of Infectious Disease Annunziata Hospital, 87100 Cosenza, Italy; filippo.luciani@gmail.com \\ 4 Operative Unit of Clinical Pharmacology and Pharmacovigilance, Mater Domini Hospital, Department of \\ Health Science, University of Catanzaro, Research Center FAS@UMG University of Catanzaro, Medifarmagen \\ SRL, Spin Off University of Catanzaro, 88100 Catanzaro, Italy \\ * Correspondence: gallelli@unicz.it
}

check for updates

Citation: Colosimo, M.; Citraro, M.L.; Donato, C.; Luciani, F.; Gallelli, L.; Minchella, P. The Role of a Rapid Prevention of Ralstonia pickettii Growth during Dialysis in a Frail Patient. Reports 2021, 4, 39. https:/ / doi.org/10.3390/reports4040039

Academic Editor: Toshio Hattori

Received: 9 November 2021

Accepted: 26 November 2021

Published: 30 November 2021

Publisher's Note: MDPI stays neutral with regard to jurisdictional claims in published maps and institutional affiliations.

Copyright: (C) 2021 by the authors. Licensee MDPI, Basel, Switzerland. This article is an open access article distributed under the terms and conditions of the Creative Commons Attribution (CC BY) license (https:/ / creativecommons.org/licenses/by/ $4.0 /)$.

\begin{abstract}
Ralstonia pickettii is an opportunistic bacillus found in Pseudomonas species, with the ability to induce systemic infections. We report the case of a 69-year-old man, with a clinical history of myeloma, Type IIdiabetes, renal failure (grade IV), and colon cancer, that developed a severe bacterial infection, with acute asthenia and a fever, that appeared at the end of dialysis. Using theMALDI-TOF technology, the bacillus Ralstonia pickettii was identified, and an antimicrobial treatment was quickly started with a rapid microbiological remission.
\end{abstract}

Keywords: Ralstonia pickettii; infection; MALDI-TOF technology; antimicrobial treatment

\section{Introduction}

Ralstoniapickettii, isolated in 1973, was originally included in the genus Pseudomonas spp. It was later reclassified into the genus Burkholderia, while the genus Ralstonia was named in 1995 [1-4]. Even if it has low virulence, it can contaminate both domestic and hospital water solutions, inducing the development of systemic infections [5], particularly in immunocompromised patients [6-8]. Herein, we report the case of a frail patient that developed a severe bacterial infection after dialysis. Ralstonia pickettii was quickly identified using a massspectrometry analytical method, in which the ion source is matrix-assisted laser desorption/ionization (MALDI), and the mass analyzer is time-of-flight (TOF) analyzer (MALDI-TOF). In particular, Horneffer et al. [9] documented that MALDI-TOF represents a rapid and sensitive method for bacterial identification. Moreover, Feli and Dellaglio suggested that this method can be used to study bacterial taxonomic and inter-and intraspecific diversity [10]. We report the case of an elderly patient that developed a bacterial infection during dialysis, which was quickly diagnosed using MALDI-TOF technology.

\section{Case Report}

A 69-year-old man with a clinical history of myeloma (2008), Type II diabetes, renal failure (grade IV), and colon cancer presented us with acute asthenia and a fever of $38^{\circ} \mathrm{C}$. He was quickly hospitalized and referred forsymptoms and fever appearing at the end of dialysis. The biochemical and microbiological evaluation from the blood sample revealed a severe increase in procalcitonin plasma levels (procalcitonin $21.12 \mathrm{ng} / \mathrm{mL}$; normal range $<0.5 \mathrm{ng} / \mathrm{mL}$ ), and the blood culture isolated a gram-negative bacterium. Biochemical blood tests documented a significant decrease in blood cells (red cells $2.66 \times 10^{6} / \mathrm{mL}$; white cells $3.53 \times 10^{3} / \mathrm{mL}$, platelets $\left.102 \times 10^{3} / \mathrm{mL}\right)$ and in hemoglobin $(8.5 \mathrm{~g} / \mathrm{dL}$; normal values 13.8 to $17.2 \mathrm{~g} / \mathrm{dL}$ ). Taken together, clinical and laboratory data suggested bacterial 
sepsis. Therefore, an empirical treatment with ceftazidime ( $2 \mathrm{~g} /$ day) was started. Three days later, both clinical evaluation and laboratory tests documented the persistence of infection (fever $38.5^{\circ} \mathrm{C}$; C-reactive protein $41.5 \mathrm{mg} / \mathrm{L}$, normal range $<10 \mathrm{mg} / \mathrm{L}$; PCT $36.2 \mathrm{ng} / \mathrm{mL}$; red cells $2.65 \times 10^{6} / \mathrm{mL}$; white cells $3.52 \times 10^{3} / \mathrm{mL}$, platelets $100 \times 10^{3} / \mathrm{mL}$, lipopolysaccharide $0.48 \mathrm{pg} / \mathrm{mL}$, hemoglobin $8.7 \mathrm{~g} / \mathrm{dL}$ ). The venous catheter for dialysis was removed, and a blood sample was taken for a new microbiology evaluation. Laboratory culture on ablood agar plate isolated a non-fermenting gram-negative oxidase-positive bacillus.

The sample was then analyzed using an automated mass spectrometry microbial identification system with the MALDI-TOF technology (bioMérieux Italia SpA, 50012 Grassina Florence, Italy). Briefly, in agreement with the literature [11], the sample was prepared by mixing or coating a solution of an energy-absorbing organic compound called the matrix. When the matrix crystallizes while drying, the sample embedded in the matrix co-crystallizes. A characteristic spectrum known as the peptide mass fingerprint (PMF) is generated for the analytes in the sample based on the TOF information [11]. TheMALDI-TOF compared the PMF of bacteria in an unknown sample with the PMF contained in the database and identified it as Ralstonia pickettii (Figure 1).

The antibiogram documented a high resistance to cefotaxime (MIC 8) and ceftazidime (MIC 16), and a susceptibility to imipenem (MIC 0.25) and meropenem (MIC 2). An intermedium resistance was reported for ciprofloxacin (MIC 0.5) and piperacillin/tazobactam (MIC 8). Ceftazidime was dismissed and meropenem (2 gr/day) was added, with a clinical improvement in about 10 days.

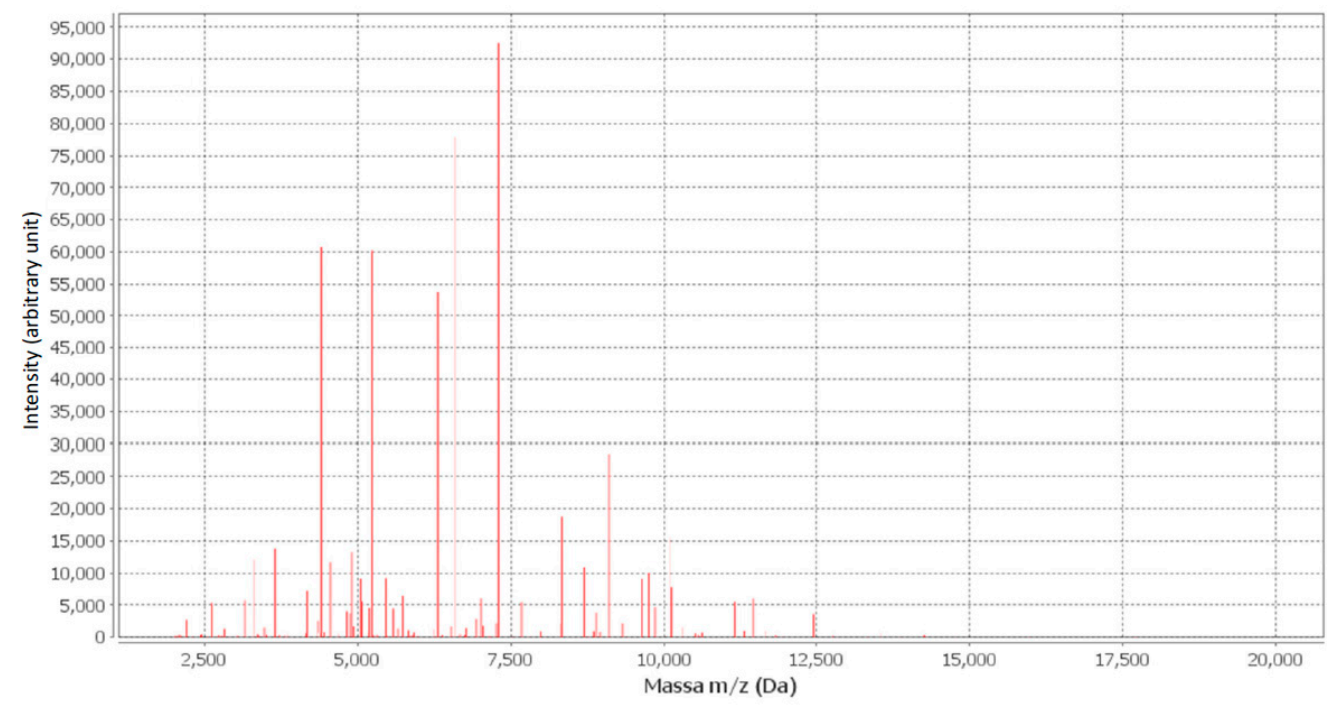

Figure 1. Maldi-TOF spectra of bacterial isolates from blood sample, using myla data processing it was identified as Ralstonia pickettii.

\section{Discussion}

We described the role of MALDI-TOF in the rapid prevention of Ralstonia pickettii (R. pickettii) growth during dialysis. Previously, Chen et al. [12], reviewing literature data, reported several gram-positive and gram-negative bacteria. Both can form biofilms on medical devices (e.g., Enterococcus faecalis, Staphylococcus aureus, Staphylococcus epidermidis, Streptococcus viridans, E. coli, Klebsiella pneumonia, Proteus mirabilis and Pseudomonas aeruginosa). In particular, these authors documented that $S$. aureus and S. epidermidis cause about $40-50 \%$ of prosthetic heart valve infections, $50-70 \%$ of catheter biofilm infections, and $87 \%$ of bloodstream infections [12]. Considering these epidemiological data, inappropriate treatment could be started in the absence of bacterial isolation. In the present case, treatment with ceftazidime was started without improving infection. Several years ago, Kimura et al. [13] and Anderson et al. [14] described the presence of R. pickettii in a wide range of temperatures $\left(15-42^{\circ} \mathrm{C}\right)$ and saline solution $[13,14]$. Moreover, Dobrowsky et al. [15] 
detected R. pickettii in dialysis water treatment facilities equipped with chlorinated polyvinyl chloride (PVC-C) piping, suggesting that PVC-C promotes the growth of R. pickettii biofilms. In contrast, the residual organic carbon in purified dialysis water promotes substantial growth of planktic $R$. pickettii and can form biofilms inside plastic catheters. In a recent review, Yiek et al. [16] found 11 reports of hemodialysis-associated outbreaks. Even if uncommon, they reported that tubing within the dialysis machine might be the site of biofilm development. These authors observed that patients became infected because the dialysis water exceeded the maximum amount of chemical and microbial contaminants, due to lack of disinfection [16]. Moreover, treated water is often stored in reservoirs, where it is distributed to dialysis machines. It has been documented that water stagnancy induced bacterial contamination of the water in the pipe systems [17].

Other sources of contamination were related to inadequate cleaning procedures that left leaking connections of the RO tubing. Biofilm-forming bacteria and other microorganisms present in cleaning solutions could have entered the water system through this opening. It is known that tubing connections are critical segments of the system and are a possible site for biofilm development [18].

In our patient, we can suppose that the infection could be related to dialysis symptoms that appeared after the dialysis, and other infection causes were ruled out. Unfortunately, however, we are not able to document it. However, the essential novelty of this presentation is represented by the use of MALDI-TOF technology forthe rapid identification of uncommon microorganisms in a particular procedure, to induce both the prevention of microbial growth and appropriate antimicrobial treatment in frail patients.

Author Contributions: Conceptualization, M.C. and M.L.C.; methodology, M.C. and L.G.; validation, C.D., F.L. and P.M.; formal analysis, M.C.; investigation, M.C., M.L.C. and C.D.; resources, P.M.; data curation, M.C.; writing-original draft preparation, M.C., M.L.C., C.D., F.L.; writing-review and editing, L.G.; supervision, P.M. All authors have read and agreed to the published version of the manuscript.

Funding: This research received no external funding.

Institutional Review Board Statement: The study was conducted according to the guidelines of the Declaration of Helsinki, and approved by the Ethics Committee (Calabria Centro).

Informed Consent Statement: Informed consent was obtained from the patient.

Data Availability Statement: Data are available in the medical records present in the Pugliese Ciaccio hospital archives.

Conflicts of Interest: The authors declare no conflict of interest.

\section{References}

1. Ryan, M.P.; Pembroke, J.T.; Adley, C.C. Ralstonia pickettii: A persistent gram-negative nosocomial infectious organism. J. Hosp. Infect. 2006, 62, 278-284. [CrossRef] [PubMed]

2. Kendirli, T.; Ciftici, E.; Ince, E.; Incesoy, S.; Güriz, H.; Aysev, A.D.; Tutar, E.; Yavuz, G.; Dogru, U.R. Ralstonia pickettii outbreak associated with contaminated distilled water used for respiratory care in paediatric intensive care unit. J. Hosp. Infect. 2004, 27, 37-38. [CrossRef] [PubMed]

3. Centers for Disease Control and Prevention (CDC). Nosocomial Ralstonia pickettii colonization associated with intrinsically contaminated saline solution-Los Angeles California 1998. MMWR. Morb. Mortal. Wkly. Rep. 1998, 47, $285-286$.

4. Ryan, M.P.; Pembroke, J.T.; Adley, C.C. Genotypic and phenotypic diversity of Ralstonia pickettii and Ralstonia insidiosa isolates from clinical and environmental sources including high-purity water. Diversity in Ralstonia pickettii. BMC Microbiol. 2011, 11, 194. [CrossRef]

5. Yin-Yin, C.; Wan-Tsuei, H.; Chia-Ping, C.; Shu-Mei, S.; Kuo, F.-M.; Chan, Y.-J.; Kuo, S.-C.; Wang, F.-D. An outbreak of Ralstonia pickettii bloodstream infection associated with an intrinsically contaminated normal saline solution. Infect. Control Hosp. Epidemiol. 2017, 38, 444-448.

6. Ryan, M.P.; Adley, C.C. Ralstonia spp: Emerging global opportunistic pathogens. Eur. J. Clin. Microbiol. Infect. Dis. 2014, 33, 291-304. [CrossRef]

7. Teiera, D.; Limongi, G.; Bertullo, M.; Cancela, M. Ralstonia pickettii bacteriemia in haemodialysis patients: A report of two cases. Rev. Bras. Ter. Intensiva 2016, 28, 195-198. 
8. Nasir, N.; Sayeed, M.; Jamil, B. Ralstonia pickettii bacteriemia: An emerging infection in a tertiary care hospital setting. Cureus 2019, 11, e5084. [CrossRef] [PubMed]

9. Horneffer, V.; Forsmann, A.; Strupat, K.; Hillenkamp, F.; Kubitscheck, U. Localization of analyte molecules in MALDI preparations by confocal laser scanning microscopy. Anal. Chem. 2001, 73, 1016-1022. [CrossRef] [PubMed]

10. Felix, G.; Dellaglio, F. On the species descriptions based on a single strain: Proposal to introduce the status species proponenda (sp. pr.). Int. J. Syst. Evol. Microbiol. 2007, 57, 2185-2187. [CrossRef] [PubMed]

11. Han, S.-S.; Jeong, Y.-S.; Choi, S.-K. Current Scenario and Challenges in the Direct Identification of Microorganisms Using MALDI TOF MS. Microorganisms 2021, 9, 1917. [CrossRef] [PubMed]

12. Chen, M.; Yu, Q.; Sun, H. Novel strategies for the prevention and treatment of biofilm related infections. Int. J. Mol. Sci. 2013, 14, 18488-18501. [CrossRef] [PubMed]

13. Kimura, A.C.; Calvet, H.; Higa, J.I.; Frank, C.; Padilla, G.; Arduino, M.; Vugia, D.J. Outbreak of Ralstonia pickettii bacteremia in a neonatal intensive care unit. Pediatr. Infect. Dis. J. 2005, 24, 1099-1103. [CrossRef] [PubMed]

14. Anderson, R.L.; Bland, L.A.; Favero, M.S.; McNeill, M.M.; Davis, B.J.; Mackel, D.C.; Gravelle, C.R. Factors associated with Pseudomonas pickettii intrinsic contamination of commercial respiratory therapy solutions marketed as sterile. Appl. Environ. Microbiol. 1985, 50, 1343-1348. [CrossRef] [PubMed]

15. Dobrowsky, M.; Kirschner, A.; Sommer, R. PVC-piping promotes growth of Ralstonia pickettii in dialysis water treatment facilities. Water Sci. Technol. 2013, 68, 929-933. [CrossRef] [PubMed]

16. Yiek, W.-K.; Coenen, O.; Nillesen, M.; van Ingen, J.; Bowles, E.; Tostmann, A. Outbreaks of healthcare-associated infections linked to water-containing hospital equipment: A literature review. Antimicrob. Resist. Infect. Control. 2021, 10, 77. [CrossRef] [PubMed]

17. Oumokhtar, B.; Lalami Ael, O.; Mahmoud, M.; Berrada, S.; Arrayhani, M.; Houssaini, T.S. Prevent infection linked to the dialysis water in a hemodialysis center in Fez city (Morocco). Pan Afr. Med. J. 2013, 16, 122. [CrossRef]

18. Bryers, J.D. Medical biofilms. Biotechnol Bioeng. 2008, 100, 1-18. [CrossRef] [PubMed] 